\title{
Dano ao "Projeto de Vida" Um Novo Horizonte às Reparações Dentro do Sistema Interamericano de Direitos Humanos?
}

\section{Candelaria Aráoz Falcón}

Mestranda em Direito Internacional dos Direitos Humanos pela Facultad de Derecho de la UBA.

candearaoz@hotmail.com

\section{Resumo:}

0 presente artigo possui como tema o "dano ao projeto de vida", um novo conceito incorporado em matéria de reparações a graves violações de direitos humanos. 0 objetivo será analisar o surgimento e percurso deste dano na jurisprudência da Corte Interamericana de Direitos Humanos. A partir desta análise jurisprudencial serão ressaltadas as dificuldades bem como a falta de uniformidade nas decisões da corte ante a casos que possuem características similares.

Palavras-Chave: Dano ao projeto de vida. Corte Interamericana de Direitos Humanos (Corte IDH). Reparações. Direitos humanos.

\section{DAMAGE TO THE "LIFE PROJECT": A NEW HORIZON OF REPARATIONS WITHIN THE INTERAMERICAN SYSTEM OF HUMAN RIGHTS?}

\begin{abstract}
:
The main topic of this article is "damage to life project", a new concept adopted in the field of reparations to gross human rights violations. The purpose of this study is to analyse the emergence and course of this damage in the jurisprudence of the Interamerican Court of Human Rights. From this judicial review will be highlighted the difficulties and the lack of uniformity in Court decisions in cases that have similar characteristics.
\end{abstract}

Keywords: Damage to life project. Interamerican Court of Human Rights. Reparations. Human rights. 


\section{Sumário:}

1. Introdução. 2. 0 Percurso da Jurisprudência da corte Interamericana de Direitos Humanos. 2.1 Sentenças que Garantem o Direito ao Projeto de Vida e Reparam seu Dano de Maneira Autônoma. 2.2 Sentenças que Reconhecem o Direito ao Projeto de Vida, mas não Reparam seu Prejuízo de Maneira Autônoma. 2.3 Sentenças que não Desenvolvem o Direito ao Projeto de Vida nem Reparam sua Violação de Maneira Autônoma. 3. Considerações Finais. 4. Referências. 
El más grave daño que se puede causar a la persona es aquel que repercute de modo radical en su "proyecto de vida", es decir, aquel acto dañino que impide que el ser humano se realice existencialmente de conformidad con dicho proyecto libremente escogido, atendiendo a nuestra personal vocación" (Fernandez Sessarego, 1985).

\section{INTRODUÇÃO}

O objetivo deste ensaio é realizar uma análise sobre o surgimento de um novo conceito incorporado em matéria de reparações a graves violações de direitos humanos. Tal noção conhecida como "dano ao projeto de vida, ${ }^{\prime}$ " surge, no plano internacional, no âmbito do Sistema Interame-

\footnotetext{
${ }^{1}$ Não se encontra disponível no direito nacional comparado disposições relativas ao dano ao projeto de vida. A jurisprudência e doutrina, entretanto, avançaram mais na matéria, embora com certas variantes terminologias e de conteúdo: "Ver (Couto; Silva, 1997, p. 217-34: A doutrina italiana inicialmente se referiu ao dano à vida de relação (danno alla vita di relazione), uma espécie de dano ao relacionamento social, concebido de acordo com as atividades sociais. Inicialmente foi concebido na ofensa física ou psíquica que impedia a pessoa de desfrutar os prazeres propiciados por atividades recreativas, sociais e esportivas, de modo a influenciar no seu estado de ânimo. Note-se que prepondera ainda elemento psicológico, em que as atividades sociais adquirem um profundo valor no mundo atual, mas em função de sentimentos do indivíduo. Este dano é próximo do préjudice d'agrément do direito Francês. Posteriormente, em uma sentença da Corte Constitucional, proferida em 1986 se introduziu o conceito de dano biológico ou dano à saúde (danno biologico, danno alla salute), como indenizável independentemente de um prejuízo patrimonial e de que o dano, como exige a lei italiana, seja decorrente de um ilícito penal". "Ver Ottonello (Ottonello, 2012): A Corte considerou tuteláveis direitos e interesses da pessoa, com sede na Constituição como o direito à saúde. A Corte de Cassação posteriormente ampliou estes direitos, especialmente no que concerne à liquidação do Dano (Cassazione 8.260, del 13.09.1996; Cassazione 8.443, del 24.09.1996); Cassazione 10.015, del 15.11.1996); As sentenças 500/99 e 7.713/ 2000, da Corte de Cassação Italiana introduzem a noção de Dano existencial (danno esistenziale), como violação ao ser, buscando reparar posições constitucionalmente protegidas. Interessante caso comparativo é da Senteza 7.713 que envolveu um caso de abandono material de um filho. $\mathrm{O}$ pai mesmo absolvido criminalmente - porque o filho era sustentado pela mãe e, pago os valores alimentícios atrasados, foi o pai condenado pela corte de Veneza, por configurar . direitos igualmente fundamentais da pessoa, configurando um dano existencial e à vida de relação". Ver Frota (2011, p. 243): “O dano existencial representa, em medida mais ou menos relevante, uma alteração substancial nas relações familiares, sociais, culturais, afetivas, etc. Abrange todo acontecimento que incide, negativamente, sobre o complexo de afazeres da pessoa, sendo suscetível de repercutirse, de maneira consistente - temporária ou permanentemente - sobre a sua existência”. Este conceito de Frota está em contradição com a construção italiana que engloba no conceito
} 
ricano de Direitos Humanos, sobretudo por meio da jurisprudência da Corte Interamericana de Direitos Humanos (Corte, Corte IDH ou Corte Interamericana). A dificuldade de avaliação deste dano, contudo, emerge na falta de precisão e continuidade de sua jurisprudência, encontrando-se casos em que a Corte IDH amalgama o conceito de dano ao projeto de

de dano existencial também danos biológicos que tem natureza pecuniária. In: Schäfer, Gilberto; Martins Machado, Carlos Eduardo. A reparação do dano ao projeto de vida na Corte Interamericana de Direitos Humanos. Revista de Direitos Fundamentais e Democracia, Curitiba, v. 13, n. 13, p. 186, jan./jun. 2013.

${ }^{\mathrm{T}}$ ambém pode se encontrar informação em: Mosset Iturraspe, Jorge. El valor de la vida humana, tercera edición, cit.; Iribarne, Héctor Pedro, El conocimiento y el cálculo matemático en la determinación de las indemnizaciones por daños a las personas, en autores varios, “Derecho de Daños”, Libro Homenaje a Jorge Mosset Iturraspe, Ediciones La Rocca, Buenos Aires, 1989; Kemelmajer de Carlucci, Aída, El daño a la persona. ¿ Sirve al derecho argentino la creación pretoriana de la jurisprudencia italiana?, en "Revista de Derecho Privado y Comunitario”, № 1, Rubinzal-Culzoni, Santa Fe, 1992; Mosset Iturraspe, Jorge, El daño fundado en la dimensión del hombre, en la "Revista de Derecho Privado y Comunitario”, № 1, Rubinzal-Culzoni, Santa Fe, 1992; Bueres, Alberto J. y Vásquez Ferreyra, Roberto A., El daño a la persona en la jurisprudencia, en la "Revista de Derecho Privado y Comunitario”, № 1, Santa Fe, 1992; Rivera, Julio César, Responsabilidad civil por daños a los derechos de la personalidad, en "Revista de Derecho Privado y Comunitario", Santa Fe, 1992; Lorenzetti, Ricardo, La lesión física a la persona. El cuerpo y la salud. El daño emergente y el lucro cesante, en "Revista de Derecho Privado y Comunitario", № 1, Santa Fe, 1992; Iribarne, Héctor Pedro, De los daños a la persona, Ediar, Buenos Aires, 1993; Zavala de González, Matilde, Daños a las personas. Integridad sicofísica, $2^{\mathrm{a}}$, Editorial Hammurabi, Buenos Aires, 1990; Zavala de González, Matilde, Resarcimiento de daños. Daños a las personas, 2b, Editorial Hammurabi, Buenos Aires, 1991; Zavala de González, Matilde, Resarcimiento de daños. Daños a las personas.Integridad espiritual y social, 2c, Editorial Hammurabi, Buenos Aires, 1994; Goldenberg, Isidoro, Daños a los derechos de la personalidad, en autores varios, “Derecho de daños”, Editorial La Rocca, Buenos Aires,1989; Daray, Hernán, Daño psicológico, Editorial Astrea, Buenos Aires, 1995; Mosset Iturraspe, Jorge, El daño a la persona en el Código civil peruano, en autores varios, "Los diez años del Código civil peruano: balance y perspectiva”, Universidad de Lima y W.G. Editores, Lima, 1995; Mosset Iturraspe, Jorge, Más allá del daño moral: el daño a la persona, en autores varios, "Los diez años del Código civil peruano: balance y perspectiva”, Universidad de Lima y W. G. Editor, Lima, 1995; Mosset Iturraspe, Jorge, Daño moral. Noción. Crítica a la denominación. Daño a la persona, en “Revista de Derecho de Daños”, № 6, Ruibinzal-Culzoni, Buenos Aires1999. Dentro de una posición tradicional, Pizarro, Daniel, Daño Moral, Editorial Hammurabi, Buenos Aires, 1996. In: "El daño al proyecto de vida em la jurisprudencia de la Corte Interamericana de Derechos Humanos" Carlos Fernández Sesarrego. Disponivel em: <https:// docs.google.com/document/d/1qPyXSXy-bFITA8daUsLN_-Om93KLxQ-VbfhbalSvul0/ edit?hl=es\&pli=1>. Aceso em: 23 de abril de 2014. 
vida e sua reparação de maneira ampla e positiva, como também casos similares em que a Corte se distancia de sua linha mais garantista, como será visto ao longo do presente ensaio.

Em um primeiro momento a Corte Interamericana entendeu que o projeto de vida "se associa ao conceito de realização pessoal, e que o mesmo sustenta-se nas opções que o sujeito pode ter para conduzir sua vida, e alcançar o destino que se propõe”. Segundo a Corte nestas decisões “tais opções são a expressão e a garantia da liberdade”. Nas palavras do Tribunal "dificilmente pode se dizer que uma pessoa é verdadeiramente livre se não possui opções para encaminhar sua existência, de maneira a conduzi-la para sua plena realização”2 (Corte IDH, 1998, Serie C No. 42, p. 39). Neste sentido, segundo Carlos Fernández Sessarego,

Entende- se por dano ao projeto de vida aquela lesão que por sua transcendência, desloca o sentido existencial da pessoa e incide sobre a liberdade do sujeito a realizar-se segundo sua livre decisão. É um dano de tal magnitude que afeta a maneira com que o sujeito decidiu viver e frustra o destino da pessoa. É, por isso, um dano contínuo e certo, cujas consequências dificilmente poderão ser superadas com o transcurso do tempo ${ }^{3}$ (1996).

\section{$[\ldots]$}

Comparando-se o dano ao projeto de vida com o dano moral encontramos uma importante diferença: as consequiências do dano moral afetam os sentimentos e os afetos da pessoa, mas por profundas que possam ser,

${ }^{2}$ Tradução livre. No original: "El proyecto de vida, 'se asocia al concepto de realización personal, que a su vez se sustenta en las opciones que el sujeto puede tener para conducir su vida y alcanzar el destino que se propone'. Estas opciones 'son la expresión y garantía de la libertad'. Dificilmente se diría que una persona es 'verdaderamente libre si carece de opciones para encaminar su existencia y llevarla a su natural culminación”.

${ }^{3}$ Tradução livre. No original: "El daño al proyecto de vida es aquella lesión que, por su trascendencia, trastoca el sentido existencial de la persona e incide sobre la libertad del sujeto a realizarse según su propia libre decisión. Es un daño de tal trascendencia que afecta la manera en que el sujeto ha decidido vivir, que frustra el destino de la persona. Es, por ello, un daño cierto y continuado, cuyas consecuencias dificilmente logran ser superadas con el transcurso del tiempo". 
não acompanham o sujeito, pelo menos com a intensidade inicial, durante o transcurso de sua vida; estas consequiências, as dores e sofrimentos tendem a dissipar-se, diminuindo ou atenuando-se com o passar do tempo. É portanto, impossível confundir as consequiências freqüentemente devastadoras do dano ao projeto de vida, com aquelas outras de natureza afetiva que são constitutivas do dano moral ${ }^{4}$ (Fernandez Sessarego, 1985).

Como é possível observar em primeira instância, a Corte IDH e o citado autor coincidem com a ideia de dano ao projeto de vida como uma lesão que, por sua magnitude, suas caraterísticas e suas consequências, incide na liberdade do sujeito, impedindo-o de alcançar sua realização pessoal e cumprir as metas que dão sentido próprio a sua vida.

Por este motivo, é importante que não somente a Corte Interamericana assegure de maneira progressiva uma reparação mais exaustiva à interrupção ou frustração do projeto de vida, mas também os tribunais nacionais, pois este conceito se relaciona diretamente com a liberdade, possibilidades de desenvolvimento e autorrealização do ser humano.

\section{O PERCURSO DA JURISPRUDÊNCIA DA CORTE INTERAMERICANA DE DIREITOS HUMANOS}

O precedente da Corte Interamericana referente ao dano ao projeto de vida, pode ser encontrado no caso Loayza Tamayo Vs. Perú (Corte IDH, 1998, Serie C No. 42). Esta foi a primeira vez na história da jurisprudência da Corte IDH, em que se reconheceu a autonomia conceitual do dano ao

\footnotetext{
${ }^{4}$ Tradução livre. No original: "Si comparamos el daño al proyecto de vida con el daño moral, podemos encontrar una importante diferencia. Las consecuencias del daño moral, si bien afectan los sentimientos y los afectos de la persona, por hondas que puedan ser, no suelen acompañar al sujeto, al menos con la intensidad inicial, durante su transcurso vital. Dichas consecuencias, los dolores y sufrimientos, suelen disiparse, disminuir, o atenuarse con el pasar del tiempo. Es, pues, imposible confundir las consecuencias, frecuentemente devastadoras del daño al proyecto de vida, con aquellas otras, de naturaleza afectiva, que son constitutivas del daño moral".
} 
projeto de vida, paralelo ao dano material e moral sofrido pelas vítimas. A Corte, deste modo, diferenciou o dano ao projeto de vida por um lado e o dano emergente e lucro cessante pelo outro. Segundo esta,

O dano ao projeto de vida não corresponde ao prejuízo patrimonial derivado imediata e diretamente dos fatos, característico do dano emergente; e tampouco pode se confundir com o lucro cessante, porque este se refere exclusivamente a perdas econômicas futuras, possíveis de quantificar a partir de certos indicadores mensuráveis e objetivos. $\mathrm{O}$ denominado projeto de vida por sua parte, atende à realização integral da pessoa afetada, considerando sua vocação, atitudes, circunstâncias, potencialidades e aspirações que lhe permitem determinar razoavelmente certas expectativas e atingi-las ${ }^{5}$ (Corte IDH, 1998, Serie C No. 42, p. 147).

Na opinião dos juízes da Corte, o projeto de vida,

[...] não se traduz num resultado seguro, de caráter necessário, mas implica uma situação provável, não meramente possível, dentro do natural e previsível desenvolvimento do sujeito, que resulta interrompido e contrariado por fatos que violem seus direitos humanos. Tais fatos mudam drasticamente o curso da vida, impõem circunstâncias novas e adversas e modificam os planos e projetos que uma pessoa formula à luz das condições ordinárias em que se desenvolve sua existência e de suas próprias atitudes para levá- los a cabo com probabilidade de êxito ${ }^{6}$ (Corte IDH, 1998, Serie C No. 42, p. 149).

${ }_{5}^{5}$ Tradução livre. No original: "El daño al proyecto de vida no corresponde a la afectación patrimonial derivada inmediata y directamente de los hechos, que es lo característico del daño emergente; y tampoco se confunde con el lucro cesante, porque 'mientras éste se refiere en forma exclusiva a la pérdida de ingresos económicos futuros, que es posible cuantificar a partir de ciertos indicadores mensurables y objetivos, el denominado [proyecto de vida] atiende a la realización integral de la persona afectada, considerando su vocación, aptitudes, circunstancias, potencialidades y aspiraciones, que le permiten fijarse razonablemente determinadas expectativas y acceder a ellas"”.

${ }^{6}$ Tradução livre. No original: "El proyecto de vida no se traduce en un resultado seguro, de carácter necesario. Sólo implica una "situación probable - no meramente posible - dentro del natural y previsible desenvolvimiento del sujeto, que resulta interrumpido y contrariado por 
Apesar de sua admissão, este dano não foi objeto de indenização por parte do Tribunal, argumentando o mesmo que “[...] a evolução da jurisprudência e da doutrina não permite, de momento, traduzir esse reconhecimento em termos econômicos, razão pela qual a Corte IDH se absteve de quantificá- lo”, advertindo que “[...] ]o acesso da vítima à jurisprudência internacional e à emissão da sentença, implicam um princípio de satisfação na ordem das considerações” (Corte IDH, 1998, Serie C No. 42, p. 153).

O conteúdo da sentença que constata a existência do dano ao projeto de vida apresenta, em si, um fenômeno significativo. Resulta insuficiente, contudo, o argumento da Corte de não quantificar o dano alegando a falta de antecedentes jurisprudenciais. Não teria perdido esta uma excelente oportunidade de estabelecer o precedente na matéria?

Esta falta de precisão na decisão da Corte IDH viu-se refletida na análise dos votos individuais de cada um dos juízes. Depreende-se de tal análise que, desde o começo, a possibilidade de uma concordância acerca da interpretação do conceito de dano ao projeto de vida apresentou dificuldades significativas entre os membros da Corte. A leitura dos votos demonstra claramente que ainda não existia entre os juízes um consenso e uma clareza tal que permitisse afirmar, de maneira concreta, a existência real de um dano ao projeto de vida e, consequentemente, a possibilidade de ordenar uma medida de reparação adequada.

hechos violatorios de sus derechos humanos". Tales hechos "cambian drásticamente el curso de la vida, imponen circunstancias nuevas y adversas y modifican los planes y proyectos que una persona formula a la luz de las condiciones ordinarias en que se desenvuelve su existencia y de sus propias aptitudes para llevarlos a cabo con probabilidades de éxito”.

7 Tradução livre. No original:"La evolución de la jurisprudencia y la doctrina hasta la fecha no permite traducir este reconocimiento en términos económicos, y por ello el Tribunal se abstiene de cuantificarlo. Advierte, no obstante, que el acceso mismo de la víctima a la jurisdicción internacional y la emisión de la sentencia correspondiente implican un principio de satisfacción en este orden de consideraciones". 
Neste sentido, pode-se citar o voto fundamentado do juiz Oliver Jackman, que não compartilha com a ideia de criação de um novo ramo em matéria de reparações. Para este último, “o dano ao projeto de vida, como a Corte o define, pode ser incluído em outros ramos”, embora não explica quais seriam os adequados e nem porque (Voto Juíz Jackman, Corte IDH, 1998, Serie C No. 42).

Por outro lado, o juiz Carlos Vicente de Roux expõe, em seu voto parcialmente dissidente, uma opinião totalmente diferente da opinião de Jackman, considerando que “[...] é um grande avanço incorporar o dano ao projeto de vida como uma questão autônoma e diferente das outras categorias [...]”, mas segundo ele “[...] a Corte deveria fixar uma indenização monetária ao fato” (Voto Juíz Vicente de Roux, Corte IDH, 1998, Serie C No. 42).

Finalmente os juízes A. Cançado Trindade e A. Abreu Burelli apoiaram plenamente a decisão da Corte e ressaltaram a importância de considerar certos danos e suas reparações fora do alcance meramente econômico, deixando aberta a via para um maior desenvolvimento da jurisprudência.

Partindo deste paradigmático caso, será analisada a jurisprudência da Corte segundo as diferentes posições adotadas pela mesma ao longo dos últimos quinze anos, dividindo as sentenças em três grupos: aquelas que garantem plenamente o direito ao projeto de vida e reparam sua violação de maneira autônoma; aquelas que reconhecem o dano ao projeto de vida mas não reparam o mesmo ou incluem ele em outros ramos indenizatórios; e aquelas que não fazem referência ao dano ao projeto de vida, mesmo em circunstâncias similares a outros casos em que se reconhece tal direito.

\subsection{Sentenças que garantem o direito ao projeto de vida e reparam seu dano de maneira autônoma}


A primeira vez que a Corte Interamericana de Direitos Humanos reparou de maneira autônoma o dano ao projeto de vida, foi no caso Cantoral Benavides Vs. Perú, em que se declarou a responsabilidade do Estado por privação ilegal da liberdade, tratos cruéis, inumanos e degradantes, entre outras violações. Aqui o Tribunal retomou o antecedente do caso Loayza Tamayo, ao reconhecer que "[...] os transtornos que os fatos impuseram ao Senhor Benavides, impediram a realização de sua vocação, aspirações e potencialidades, em particular, no que diz respeito a sua formação e a seu trabalho como profissional, representando um sério deterioramento para seu projeto de vida” (Corte IDH, 2001, Serie C No. 88, p. 23-24). Neste caso a Corte deu um passo adiante ao ordenar, como "medida de satisfação e não repetição”, uma bolsa de estudos superiores universitários para reparar o dano ao projeto de vida ${ }^{9}$ (Corte IDH, 2001, Serie C No. 88, p. 30).

${ }^{8}$ Tradução livre. No original: "Es, por otra parte, evidente para la Corte, que los hechos de este caso ocasionaron una grave alteración del curso que normalmente habría seguido la vida de Luis Alberto Cantoral Benavides. Los trastornos que esos hechos le impusieron, impidieron la realización de la vocación, las aspiraciones y potencialidades de la víctima, en particular, por lo que respecta a su formación y a su trabajo como profesional. Todo esto ha representado un serio menoscabo para su "proyecto de vida".

${ }^{9}$ Tradução livre. No original: "Estima la Corte que la vía más idónea para restablecer el proyecto de vida de Luis Alberto Cantoral Benavides consiste en que el Estado le proporcione una beca de estudios superiores o universitarios, con el fin de cubrir los costos de la carrera profesional que la víctima elija -así como los gastos de manutención de esta última durante el periodo de tales estudios- en un centro de reconocida calidad académica escogido de común acuerdo entre la víctima y el Estado". 
Pode se observar como no presente caso, a Corte IDH, não somente reconhece a existência de um dano certo ao projeto de vida da vítima, mas também se atreveu a ordenar uma medida reparatória expressamente destinada a mitigar as consequências de tal dano.

Sete anos depois no caso da Masacre de las Dos Erres Vs. Guatemala, a Corte Interamericana reconheceu que a "[...]ausência de justiça provocou uma perda de oportunidades nas vítimas e seus familiares, gerando um dano ao projeto de vida”. Nesta ocasião, porém, ordenou em relação às vítimas uma quantia de dinheiro como compensação por dano imaterial de maneira genérica. Ou seja, não reparou como, no caso antes citado, as consequências derivadas especificamente do dano ao projeto de vida. Não obstante, a Corte especificou em relação a uma das vítimas que a compensação ordenada levava em consideração, entre outras questões, "as conseqüências de natureza psicológicas e o efeito no projeto familiar". Neste sentido, o Tribunal determinou que,

No caso da vítima sobrevivente, a separação de seus familiares derivou em prejuízo, não somente psicológico mas também a seu projeto de vida dentro do seu entorno familiar, razão pela qual, ante a falta de uma medida adequada para recobrar o reordenar seu projeto de vida, procede uma indenização adicional por tais danos ${ }^{10}$ (Corte IDH, 2009, Serie C No. 211, p. 79 e 81).

\footnotetext{
${ }^{10}$ Tradução livre. No original: "La Corte advierte que de los peritajes realizados por la perito Nieves Gómez Dupuis, se desprende que "[l] a falta de justicia [...] favorece que [...] la culpa se reviert [a] en las víctimas y éstas qued[en] estigmatizadas [y que el] "miedo a que les vuelva a ocurrir lo mismo [...] hace que la reparación psicológica [sea] muy difícil, [si no] imposible”. Además, señala que las víctimas, manifestaron sentimientos de rabia, cólera, enojo, tristeza, inseguridad, desánimo, venganza e impotencia, los cuales han afectado también a la segunda generación de las victimas sobrevivientes y los familiares. Aunado a lo anterior, la ausencia de justicia provocó una pérdida de oportunidades en las víctimas sobrevivientes y los familiares provocando un daño a su proyecto de vida. Asimismo, indica que esta situación ha provocado la desvinculación de algunas personas del proceso legal por el miedo y la retraumatización que provoca hablar del caso".
} 
É de ressaltar, como a Corte nesta ocasião reconhece, a existência de um dano ao projeto de vida que resulta reparável e diferenciado do prejuízo psicológico, embora limitando-se a uma só das vítimas.

Outro caso que implica um grande aporte na matéria é o caso Furlan y Familiares Vs. Argentina, relacionado com a responsabilidade do Estado, por falta de resposta oportuna das autoridades judiciais, da qual dependia o tratamento médico de uma criança com incapacidade. No presente, a Corte IDH novamente desenvolve o conceito de projeto de vida e esta vez ordena reparar o mesmo de maneira autônoma e dentro de duas categorias indenizatórias diferentes: como medida de "reabilitação" em relação ao projeto de vida e como "indenização compensatória” por dano imaterial. Na primeira categoria a Corte IDH determinou que "a falta de devida reabilitação teve um impacto negativo nas esferas sociais, laborais e educativas da vítima, afetando gravemente seu projeto de vida”, razão pela qual ordenou ao Estado Argentino a "formação de um grupo interdisciplinar para determinar as medidas de proteção e assistência mais apropriadas para sua inclusão social, educativa, vocacional e laboral"11 (Corte IDH, 2012, Serie C No. 246, p. 92). Por outro lado, como medida compensatória por dano imaterial, esta estabeleceu que,

"Al respecto, en el caso del sobreviviente Ramiro Osorio Cristales el sufrimiento por la sustracción y retención ilegal por el Kaibil Santos López y separación de sus familiares (supra párrs. 179 y 180) derivó en afectaciones no sólo psicológicas sino también a su proyecto de vida dentro de un entorno familiar, inclusive en su destierro. En función de la falta de elementos para ordenar una medida adecuada para recobrar o reorientar su proyecto de vida, procede una indemnización adicional por dichos daños “.

${ }^{11}$ Tradução livre. No original: “[...] el Tribunal ordena al Estado argentino la conformación de un grupo interdisciplinario, el cual, teniendo en cuenta la opinión de Sebastián Furlan, determinará las medidas de protección y asistencia que serían más apropiadas para su inclusión social, educativa, vocacional y laboral. Igualmente, en la determinación de dichas medidas, se deberá tener en cuenta la asistencia necesaria para facilitar la implementación de las mismas, por lo que de manera consensuada, se deberán poner en práctica, entre otras medidas, atención a domicilio o en sitios cercanos a su residencia.[...]". 
O impacto produzido pela demora no processo judicial, não somente provocaram sentimentos de angústia, ansiedade, incerteza e frustração na vítima, mas também afetaram gravemente desde sua infância ao desenvolvimento pessoal, familiar, social e laboral, privando-a da possibilidade de construir um projeto de vida autônomo e independente.

Por esta razão a Corte IDH ordenou uma soma em dinheiro como medida compensatória ${ }^{12}$ (Corte IDH, 2012, Serie C No. 246, p. 102).

Como se pode apreciar, a Corte novamente estabeleceu uma diferenciação entre o dano moral e o dano ao projeto de vida. $O$ primeiro se relaciona com alterações nos sentimentos da pessoa, que, com o passar do tempo, tendem a diminuir. O segundo está ligado com o agravo ou frustração das opções que o sujeito tem para alcançar livremente seu desenvolvimento pessoal. Neste sentido, no caso de não acontecer o fato danoso, a vítima poderia exercer tais opções destinadas a satisfazer a razão própria de sua existência. As graves consequências do prejuízo ou aniquilamento do projeto de vida da pessoa são o que justifica que este mereça ser reparado independentemente do dano moral.

Por último, uma recente sentença proferida pela Corte IDH e possivelmente uma das mais transcendentes na matéria, foi no caso Mendoza e outros Vs. Argentina, referindo-se à aplicação de prisão perpétua no que concerne a menores. A Corte sinalizou que o dano ao projeto de vida "implica a perda ou grave detrimento de oportunidades de desenvolvi-

\footnotetext{
${ }^{12}$ Tradução livre, no original: "En el presente caso, la Corte considera que el impacto producido por la demora en el proceso judicial y su ejecución no sólo le provocaron sentimientos de angustia, ansiedad, incertidumbre y frustración, sino lo afectaron gravemente desde su niñez en su desarrollo personal, familiar, social y laboral, privándolo de la posibilidad de construir una proyecto de vida propio, autónomo e independiente". Parr, 321: "Considerando las circunstancias del presente caso, los sufrimientos que las violaciones cometidas causaron a las víctimas (supra párr. 265 y 269), así como el cambio en las condiciones de vida y las restantes consecuencias de orden inmaterial o no pecuniario que éstos últimos sufrieron, la Corte estima pertinente fijar, en equidad, a favor de Sebastián Claus Furlan una suma de US\$ 60.000 (sesenta mil dólares de los Estados Unidos de América) como compensación por concepto de indemnización por el daño inmaterial”.
} 
mento pessoal de maneira irreparável ou muito dificilmente reparável, e a reparação integral de tal dano requer medidas que vão além de uma mera reparação monetária, consistentes com medidas de reabilitação, satisfação e garantia de não repetição"13 (Corte IDH, 2013, Serie C No. 260, p. 103).

A Corte Interamericana ressaltou que "[...] é evidente como a imposição de uma pena perpetua a menores e a falta de possibilidades reais de alcançar a readaptação social, anulou suas possibilidades de formar um projeto de vida numa etapa determinante de sua formação e desenvolvimento pessoal, produzindo efeitos lesivos que acabaram com suas expectativas futuras de vida.” Por esta razão, a Corte determinou como medida de reabilitação que o Estado deveria assegurar às vítimas opções educativas ou de capacitação que elas escolhessem, incluindo educação universitária por meio do sistema penitenciário, e ordenou também ao Estado outorgar bolsas educativas para as vítimas pelo tempo que realizassem seus estudos ${ }^{14}$ (Corte IDH, 2013, Serie C No. 260, p. 104).

${ }^{13}$ Tradução livre. No original: "La Corte considera, como lo ha hecho en otros casos, que el proyecto de vida atiende a la realización integral de la persona afectada, considerando su vocación, aptitudes, circunstancias, potencialidades y aspiraciones, que le permiten fijarse razonablemente determinadas expectativas y acceder a ellas. Asimismo, se expresa en las expectativas de desarrollo personal, profesional y familiar, posibles en condiciones normales. Esta Corte ha señalado que el "daño al proyecto de vida" implica la pérdida o el grave menoscabo de oportunidades de desarrollo personal, en forma irreparable o muy difícilmente reparable. Dicho daño se deriva de las limitaciones sufridas por una persona para relacionarse y gozar de su entorno personal, familiar o social, por lesiones graves de tipo físico, mental, psicológico o emocional que se le hayan ocasionado. La reparación integral del daño al "proyecto de vida" generalmente requiere medidas reparatorias que vayan más allá de una mera indemnización monetaria, consistentes en medidas de rehabilitación, satisfacción y garantía de no repetición".

${ }^{14}$ Tradução livre, no original: “[...].para la Corte es evidente que la imposición de la pena perpetua a estos niños y la falta de posibilidades reales de alcanzar la readaptación social les anuló la posibilidad de formar proyecto de vida alguno en una etapa determinante de su formación y desarrollo personal[...]". Parr, 317: "Por lo tanto, la Corte dispone que, a la mayor brevedad, el Estado asegure a las víctimas ya mencionadas, las opciones educativas o de capacitación formales que ellos deseen, incluyendo educación universitaria, a través del sistema penitenciario o, en caso de que se encuentren en libertad, a través de sus instituciones públicas. Para estos últimos, además, el Estado deberá otorgarles una beca educativa integral por el tiempo que efectivamente realicen sus estudios, la cual deberá incluir los gastos de 
O fato de a Corte ter considerado, nesta sentença, a existência de projetos de vida de menores - mesmo privados de liberdade - e a obrigação do Estado de provê-los de ferramentas para desenvolver tais projetos e lograr a readaptação social, constitui possivelmente uns dos pronunciamentos mais significativos na matéria. Além disso, a Corte IDH especificou quais medidas podem ser adotadas para alcançar uma reparação integral no caso de dano ao projeto de vida. Medidas que, conforme o julgamento, vão além de uma mera reparação monetária.

Analisando os quatro casos anteriormente citados, pode-se afirmar que é significativo o fato de a Corte ter reconhecido a importância da reparação do dano ao projeto de vida, paralelamente a outros prejuízos dos quais a pessoa pode resultar vítima. A jurisprudência da Corte IDH constitui um considerável aporte para o desenvolvimento de medidas que representem uma reparação mais integral para as vítimas de violações de direitos humanos. Esta, contudo, ainda não adotou uma postura uniforme referente à qual medida e, portanto, qual categoria de reparação é a adequada para incluir o dano ao projeto de vida. Como se verá ao longo deste trabalho, esta falta de certeza conduziria a Corte a se abster de repará-lo em certas ocasiões, possivelmente pela dificuldade de avaliação do respectivo dano.2.2 Sentenças que reconhecem o direito ao projeto de vida mas não reparam seu prejuízo de maneira autônoma

Dentro deste grupo, encontramos a sentença do caso Villagrán Morales Vs. Guatemala, em que o Estado foi declarado responsável, dentre outras violações , pelo homicídio de um grupo de crianças de rua por parte de seus agentes. No presente caso, a Corte pareceu realizar um avanço neste conceito, estabelecendo que "toda criança tem diretos a desenvol-

transporte y material educativo idóneo para sus estudios hasta que éstos concluyan, de tal forma que puedan afrontar mejor las exigencias propias que requiere la adecuada formación educativa. El Estado deberá implementar esta medida de reparación en el plazo de un año, contado a partir de la notificación de la presente Sentencia”. 
ver um projeto de vida que deve ser cuidado e fomentado pelos poderes púbicos em seu benefício e da sociedade a qual pertence"15 (Corte IDH, 1999, Serie C No. 63, p. 49). Avançando ainda mais no tema, os juízes Cançado Trindade e Abreu Burelli, em seu voto concorrente, relacionaram a noção de projeto de vida com o direito a uma vida digna. Segundo eles, “o projeto de vida é inerente ao direito à existência e requer, para seu desenvolvimento, condições de vida digna, de segurança e integridade da pessoa humana”. Também expressaram que:

Uma pessoa que em sua infância vive, como em tantos países de América Latina, na humilhação da miséria, sem a menor condição para criar seu projeto de vida, experimenta um estado de padecimento equivalente a uma morte espiritual, a morte física que segue a esta última, em tais circunstâncias, e a culminação da destruição total do ser humano ${ }^{16}$ (Cançado Trindade; Abreu Burelli, Corte IDH, 1999, Serie C No. 63, p. 2-3).

Não obstante a Corte IDH ter desenvolvido amplamente a noção de projeto de vida na sentença de fundo ${ }^{17}$ (Corte IDH, 1999, Serie C No. 63, p. 49), no momento de ditar as medidas de reparação a Corte demostrou-se conservadora. Isso ocorre pois, apesar da Comissão Interamericana de

${ }^{15}$ Tradução livre. No original: "[...] todo niño tiene derechos a alentar un proyecto de vida que debe ser cuidado y fomentado por los poderes públicos para que se desarrollo en su beneficio y en el de la sociedad a la que pertenece”.

${ }^{16}$ Tradução livre. No original: “Creemos que el proyecto de vida es consustancial del derecho a la existencia, y requiere para su desarrollo condicionesde vida digna, de seguridad e integridad de la persona humana." "Una persona que en su infancia vive, como en tantos países de América Latina, en la humillación de la miseria, sin la menor condición siquiera de crear su proyecto de vida, experimenta un estado de padecimiento equivalente a una muerte espiritual; la morte física que a ésta sigue, en tales circunstancias, es la culminación de la destrucción total del ser humano".

${ }^{17}$ Tradução livre, no original: “Cuando los Estados violan, en esos términos, los derechos de los niños en situación de riesgo, como los 'niños de la calle', los hacen víctimas de una doble agresión. En primer lugar, los Estados no evitan que sean lanzados a la miseria, privándolos asi de unas minimas condiciones de vida digna e impidiéndoles el 'pleno y armonioso desarrollo de su personalidad', a pesar de que todo niño tiene derecho a alentar un proyecto 
Direitos Humanos (Comissão Interamericana ou CIDH) e os representantes das vítimas terem solicitado reparação ao dano do projeto de vida, separadamente do dano moral, a Corte não dedicou autonomia ao conceito e juntou-os dentro da categoria de danos imateriais (Corte IDH, 2001, Serie C No. 77, p. 40), ordenando uma compensação monetária a respeito.

Pergunta-se, entretanto: Por que a Corte, logo após ter reconhecido a lesão no direito ao projeto de vida das vítimas como consequência da ação direta de agentes do Estado, não mandou reparar tais violações de maneira autônoma? Quais são as razões que levaram a Corte a não tratar do dano ao projeto de vida separadamente do dano moral? Por que a Corte não fundamentou tal falta de distinção? Acaso existiram dificuldades para mensurar o dano? Teria sido a falta de consenso entre os juízes da Corte? Trata-se de perguntas que até o momento carecem de resposta.

Outra sentença em relação ao dano ao projeto de vida é aquela referente ao caso Tibi Vs. Ecuador, em que a Corte IDH reconhece que as violações cometidas contra Daniel Tibi "alteraram de forma manifesta seu projeto de vida”. Apesar de esta ter levado em consideração a destruição do projeto de vida, no momento de decretar as reparações a mesma se absteve de ditar medidas destinadas exclusivamente a reparar o dano ao projeto de vida, com independência do dano moral, ordenando novamente de maneira genérica uma compensação pecuniária, dentro do conceito de dano imaterial ${ }^{18}$ (Corte IDH, 2004, Serie C No. 114, p. 98) .

\footnotetext{
de vida que debe ser cuidado y fomentado por los poderes públicos para que se desarrolle en su beneficio y en el de la sociedad a la que pertenece. En segundo lugar, atentan contra su integridad física, psíquica y moral, y hasta contra su propia vida”.

${ }^{18}$ Tradução livre. No original: "Es razonable considerar que las violaciones cometidas en contra del señor Daniel Tibi alteraron de forma manifiesta su proyecto de vida. Las expectativas de desarrollo personal, profesional y familiar, posibles en condiciones normales, fueron interrumpidas de manera abrupta" "Por todo ello, la Corte considera que el señor Daniel Tibi debe ser compensado por daño inmaterial y fija en equidad la suma de $\square 82.850,00$ (ochenta y dos mil ochocientos cincuenta euros) a su favor por ese concepto".
} 
No caso Gutiérrez Soler Vs. Colombia, abriu-se novamente a esperança de uma alteração significativa na matéria. No presente caso, a Corte IDH retoma mais uma vez o conceito de dano ao projeto de vida e, como na sentença Loayza Tamayo, dedica todo um capítulo para fixar os alcances do mesmo. Apesar disso, a Corte estabeleceu que "[...] a natureza complexa e íntegra do dano ao projeto de vida exige medidas de satisfação e garantias de não repetição, que vão além da esfera econômica”, concluindo que "nenhuma forma de reparação poderia devolver ou proporcionar as opções de realização pessoal das que injustamente se viu privado o senhor Wilson Gutiérrez Soler”. Possivelmente, dada a dificuldade de avaliar o dano ocasionado, a Corte evitou reparar o mesmo, e simplesmente especificou que a publicação da sentença foi dirigida especialmente às consequências do dano ao projeto de vida ${ }^{19}$ (Corte IDH, 2005, Serie C No. 132, p. 41, 46).

A decisão da Corte IDH na presente sentença é, em certa medida contraditória. Como é possível observar, esta reconhece a existência de um dano que infringe injustamente as opções de realização pessoal da vítima, mas, ao mesmo tempo, a Corte se reserva de repará-lo alegando a impossibilidade de devolver à vítima as opções das quais se viu privada, assim como também a natureza complexa revestida pelo dano que vai além

\footnotetext{
${ }^{19}$ Tradução livre. No original: "Por las anteriores consideraciones, la Corte reconoce la ocurrencia de un daño al 'proyecto de vida' del señor Wilson Gutiérrez Soler, derivado de la violación de sus derechos humanos. Como en otros casos, no obstante, el Tribunal decide no cuantificarlo en términos económicos, ya que la condena que se hace en otros puntos de la presente Sentencia contribuye a compensar al señor Wilson Gutiérrez Soler por sus daños materiales e inmateriales. La naturaleza compleja e integra del daño al 'proyecto de vida' exige medidas de satisfacción y garantías de no repetición (infra párrs. 103, 104, 105, 107 y 110) que van más allá de la esfera económica. Sin perjuicio de ello, el Tribunal estima que ninguna forma de reparación podría devolverle o proporcionarle las opciones de realización personal de las que se vio injustamente privado el señor Wilson Gutiérrez Soler". [....] "Asimismo, la Corte estima que, como medida de satisfacción adicional con el fin de reparar el daño sustancial al proyecto de vida y honra del señor Wilson Gutiérrez Soler y de sus familiares, así como con el objeto de evitar que hechos como los de este caso se repitan, el Estado debe difundir las partes pertinentes de la presente Sentencia”.
} 
da esfera econômica. É realmente uma justificativa suficiente a dificuldade de avaliação do dano como razão para privar a vítima de uma reparação mais integral?

Evidentemente tal omissão da Corte foi objeto de novos desacordos entre seus membros, o qual se viu refletido na falta de consenso que ainda persistia entre os mesmos em referência à matéria. Assim, na opinião emanada pelo juiz Cançado Trindade, "depois dos avanços jurisprudenciais sobre o conceito de direito ao projeto de vida, a Corte teve a ocasião de avançar na construção do mesmo, mas a falta de consenso sobre que caminho tomar impossibilitou um novo avanço". Além disso, segundo o juiz, "a Corte, mesmo sem unanimidade, deveria ter dado um passo adiante enquanto a uma construção jurisprudencial ao respeito"20 (Cançado Trindade, 2005, Corte IDH, Serie C No. 132, p. 1-2).

Por outro lado, o juiz Oliver Jackman reitera sua postura do caso Loayza Tamayo, estabelecendo que "os extensos precedentes jurisprudenciais da Corte, lhe permitem avaliar o dano ao projeto de vida e ordenar as medidas pertinentes, sem necessidade de criar um novo ramo de reparações”. Segundo o juiz, “o conceito de dano compensável ligado a projeto de

${ }^{20}$ Tradução livre. No original:"Después de los avances jurisprudenciales sobre el concepto del derecho al [proyecto] de vida ....tenía la Corte la ocasión de avanzar en su construcción al respecto, pero la falta de consenso en el seno de la misma sobre qué rumbo tomar imposibilitó un nuevo avance. Sin embargo, pienso que la Corte, aun sin unanimidad, debería haber dado un paso adelante en cuanto a su construcción jurisprudencial al respecto.... 'La Corte, al ordenar al Estado demandado, en el presente caso, inter alia, la publicación de las partes relevantes de la presente Sentencia, ponderó que así lo hacía como una [medida de satisfacción adicional] a fin de [reparar el daño sustancial al proyecto de vida y honra del Sr. Wilson Gutiérrez Soler y de sus familiares], así como a fin de evitar la repetición de hechos (de tortura y malos tratos) como los del presente caso (párr. 105). Dentro de este entendimiento, con el cual estoy básicamente de acuerdo para preservar la especificidad del daño al proyecto de vida (que coexiste con el daño moral), podía y debía la Corte, sin embargo, haber procedido a un nuevo avance jurisprudencial del concepto de derecho al proyecto de vida". 
vida, além de gerar novas formas de castigo aos Estados, resulta artificial e não responde a uma necessidade jurídica identificável”21 (Jackman, Corte IDH, 2005, Serie C No. 132).

Observa-se nas palavras de alguns dos magistrados que a Corte ainda tropeçava com grandes dificuldades relativas à criação de um novo ramo em matéria de reparações.

Outra oportunidade, que também poderia ter significado um grande avanço na matéria, ocorreu no caso Artavia Murillo y otros Vs. Costa Rica, no qual a Corte IDH declarou a responsabilidade do Estado pela violação do direito à vida privada e familiar das vítimas , entre outros, como consequência da proibição geral de praticar Fecundação in vitro (FIV).

O presente caso constituía uma excelente oportunidade para que a Corte se pronunciasse mais exaustivamente sobre o direito ao projeto de vida, desenvolvendo o mesmo em uma dimensão coletiva, como dano ao projeto de vida familiar, tal como foi valorado no âmbito da sentença referente ao caso Masacre de las Dos Erres Vs. Guatemala supracitado. Apesar disso, e além do representante das vítimas ter alegado especificamente o dano ao projeto de vida em varias ocasiões, o Tribunal novamente ordenou, de maneira genérica, em conceito de equidade, uma soma monetária por dano imaterial. Tal medida respondia, segundo o Tribunal, "aos sentimentos de angústia, ansiedade, incerteza e frustração, assim como as sequelas na possibilidade de decidir um projeto de vida próprio, autônomo

\footnotetext{
${ }^{21}$ Tradução livre, no original: "Los extensos precedentes que la Corte ha establecido en su jurisprudencia le permiten, sin necesidad de crear un nuevo rubro de reparaciones, evaluar el daño al que se ha hecho referencia y ordenar las medidas pertinentes de acuerdo al artículo 63 de la Convención Americana sobre Derechos Humanos”. "[...]El concepto de daño compensable al llamado 'proyecto de vida' - aparte de la impresión que podría generar de una Corte demasiado ansiosa en encontrar formas novedosas para castigar a los estados demandados - es, en mi opinión respetuosa, artificial, y una creación que no responde a una necesidad jurídica identificable”.
} 
e independente do que foram objeto as vítimas”22 (Corte IDH, 2012, Serie C No. 257, p. 110). Surpreende particularmente que a Corte reconhecesse o impacto nos planos de vida dos casais cuja única opção de procriar fora a FIV, mas não reparasse o mesmo de maneira autônoma atendendo às circunstâncias do caso.

Como pode-se observar até aqui, e segundo os casos analisados, a Corte continua reconhecendo a importância da noção de projeto de vida como direito de toda pessoa de construir um plano de vida segundo sua livre-decisão. Da mesma maneira reconhece que o deterioramento do mesmo afeta gravemente a integridade da pessoa e o destino da mesma, mas, por determinadas razões que o Tribunal não explica, decide não reparar sua violação independentemente de outros tipos de danos.

$\mathrm{Na}$ continuidade, serão analisadas aquelas sentenças que se separam totalmente da doutrina da Corte IDH até aqui estudada. Nestas, a Corte parece desconhecer a noção de dano ao projeto de vida toda vez que não somente se abstém de reparar seu quebrantamento, mas tampouco faz referência ao mesmo, além dos representantes legais, em menores ocasiões, a Comissão Interamericana, requerer expressamente sua reparação.

\footnotetext{
${ }^{22}$ Tradução livre, no original: "En el presente caso, el Tribunal recuerda que el daño en el presente caso no depende de si las parejas pudieron o no tener hijos (supra párr. 350), sino que corresponde al impacto desproporcionado que tuvo en sus vidas el no poder ejercer de manera autónoma sus derechos (supra párrs. 317). Como quedó comprobado en el capitulo VIII, se han acreditado en este proceso los sentimientos de angustia, ansiedad, incertidumbre y frustración, las secuelas en la posibilidad de decidir un proyecto de vida propio, autónomo e independiente. En atención a los sufrimientos ocasionados a las víctimas, así como el cambio en las condiciones de vida y las restantes consecuencias de orden inmaterial que sufrieron, la Corte estima pertinente fijar, en equidad, la cantidad de US\$20.000 (veinte mil dólares de los Estados Unidos de América) para cada una de las víctimas por concepto de indemnización por daño inmaterial”.
} 


\subsection{Sentenças que não desenvolvem o direito ao projeto de vida nem reparam sua violação de maneira autônoma}

De início pode-se citar o caso Molina Theissen Vs. Guatemala, relacionado com o desaparecimento forçado de uma criança de 14 anos. No presente caso, a Corte IDH determinou que a "responsabilidade do Estado foi agravada pelo fato de que a vítima foi parte de uma prática de desaparecimento forçado levada a cabo por agentes do Estado, da qual também foram objeto crianças como forma de tortura e terror a suas famílias”23 (Corte IDH, 2004, Serie C No. 108, p. 26). Assim mesmo, a Corte Interamericana reconheceu que, como consequência dos fatos do caso, as condições de vida dos membros da família foram alteradas. Os pais e as irmãs da vítima tiveram de abandonar seus trabalhos e estudos para se dedicar por completo a sua procura. Além disso, se viram forçados a deixar seu país com destinos diferentes, o que significou deter a busca da vítima desaparecida, seus familiares, amigos, pertences e se reinserir em uma sociedade diferente, provocando a destruição do núcleo fami$\operatorname{liar}^{24}$ (Corte IDH, 2004, Serie C No. 108, p. 37). No momento de ditar as

${ }^{23}$ Tradução livre, no original: "En el presente caso, la responsabilidad del Estado por la violación de los artículos antes mencionados (supra párrs. 15 y 38), se ve agravada en cuanto que lo ocurrido al niño Marco Antonio Molina Theissen formó parte de una práctica de desaparición forzada de personas, aplicada por el Estado durante el conflicto armado interno y llevada a cabo principalmente por agentes de sus fuerzas de seguridad, de la que también fueron víctimas los niños, como una forma de torturar y de atemorizar a sus familias".

${ }^{24}$ Tradução livre, no original: “...los hechos ocurridos en el presente caso y el posterior exilio de la familia Molina Theissen alteraron las condiciones de vida de sus miembros; sus padres dejaron de trabajar para dedicarse por completo a la búsqueda de su hijo; igualmente sus hermanas renunciaron a sus trabajos y abandonaron sus estudios; la familia sintió un peligro permanente por la persecución de que fue objeto. Los padres y las hermanas de la víctima se vieron forzados a salir de Guatemala con destinos distintos, lo que significó para ellos abandonar la búsqueda de Marco Antonio, a sus familiares, amigos y compañeros de trabajo, raices y pertenencias y reinsertarse en una sociedad diferente (supra párrs. 37.8 y 37.9). Además, como quedó en evidencia en la audiencia pública (supra párrs. 11 y 30.a, 30.b, 30.c y 30.d), la familia Molina Theissen era profundamente unida y existía entre los padres y las hermanas y entre éstas últimas una estrecha relación y afecto. La separación que sufrieron, asociada a la culpa que sentían por la desaparición de Marco Antonio, desintegró el núcleo familiar". 
medidas de reparação, tanto a Comissão IDH quanto os representantes solicitaram à Corte que ordenasse ao Estado o pagamento de uma soma em dinheiro especificamente como reparação ao dano ao projeto de vida tanto da vítima como de seus familiares (Corte IDH, 2004, Serie C No. 108, p. 34-35), separadamente de outras categorias como o dano moral. Mesmo assim, esta simplesmente fixou uma compensação por dano imaterial, sem, pelo menos, mencionar o conceito de dano ao projeto de vida. Surpreende particularmente que, tendo em conta as circunstâncias do caso em que se encontraram em jogo direitos de crianças, em que se produziu a destruição íntegra de uma família e, consequentemente, a aniquilação do projeto de vida tanto individual quanto conjunto das vítimas, a Corte Interamericana não fizera alusão ao projeto de vida, nem respondera aos requerimentos da Comissão IDH ou dos representantes das vítimas. Resulta inexplicável tal comportamento da Corte. Mais inesperado, ainda, é o fato de que o mesmo não explicara a negativa de fazer lugar aos pedidos de reparação por dano ao projeto de vida e simplesmente deixara de analisar tal categoria.

Outro caso útil de mencionar e que reflete a falta de avanço da Corte na matéria se encontra na sentença Hermanos Gomez Paquiyauri vs. Perú (Corte IDH, 2004, Serie C No. 110). Apesar de se tratar da execução extrajudicial de duas crianças, e, portanto, ocasionando a perda de oportunidades de desenvolvimento pessoal, a Corte IDH se omitiu em adentrar na questão do dano ao projeto de vida na sentença de reparações e simplesmente equivale este com a perda de receita. Cabe recordar a distinção que, em casos anteriores, fez a Corte entre o dano ao projeto de vida por um lado e o lucro cessante (perda de receita) por outro. Segundo esta,

[...] aquele não se confunde com o lucro cessante porque enquanto este se refere em forma exclusiva a perda de receitas econômicas futuras, que é possível quantificar partindo de certos indicadores mensuráveis e objetivos, o denominado projeto de vida atende a realização integral da pessoa afetada, considerando sua vocação, atitudes, cir- 
cunstâncias, potencialidades e aspirações que lhe permitem determinar razoavelmente certas expectativas e atingi-las ${ }^{25}$ (Corte IDH, 1998, Serie C No. 42, p. 39).

Tal contradição na jurisprudência da Corte é ressaltada claramente pelo juiz ad hoc Francisco Eguiguren Praeli, que considerou que "teria sido preferível e mais adequado, estabelecer como critério predominante a reparação do dano ao projeto de vida ocasionado pela execução de ambas crianças, que haver considerado dentro do dano material a perda de receitas”26 (Eguiguren Praeli, Corte IDH, 2004, Serie C No. 110). Segundo o juiz,

O dano ao projeto de vida envolve tanto aspectos materiais como imateriais, e compreende assim não somente uma reparação indenizatória pela privação arbitrária da vida, mas também pela afetação e truncamento do livre-desenvolvimento da personalidade, a interrupção de atividades que puderam realizar ambas crianças não somente no laboral (perda de receita) mas também em aspectos espirituais, a realização pessoal, familiar, de planos e metas. O reconhecimento do dano ao projeto de vida, resulta mais integral e consistente desde uma perspectiva de proteção dos direitos humanos, separando-se de correntes essencialmente patrimoniais $^{27}$. (Eguiguren Praeli, 2004, Corte IDH, Serie C No. 110).

${ }^{25}$ Tradução livre, no original: "El daño al proyecto de vida no corresponde a la afectación patrimonial derivada inmediata y directamente de los hechos, que es lo característico del daño emergente; $y$ tampoco se confunde con el lucro cesante, porque 'mientras éste se refiere en forma exclusiva a la pérdida de ingresos económicos futuros, que es posible cuantificar a partir de ciertos indicadores mensurables y objetivos, el denominado [proyecto de vida] atiende a la realización integral de la persona afectada, considerando su vocación, aptitudes, circunstancias, potencialidades y aspiraciones, que le permiten fijarse razonablemente determinadas expectativas y acceder a ellas”

${ }^{26}$ Tradução livre, no original: “Respecto al tema de las reparaciones, considero que hubiera sido preferible establecer como criterio predominante la reparación del daño al proyecto de vida, ocasionado por la ejecución de ambos niños. Ello lo encuentro preferible y más adecuado que haber considerado dentro del daño material la pérdida de ingresos, como se ha he hecho en ésta y otras sentencias de la Corte”.

${ }^{27}$ Tradução livre, no original: "El daño al proyecto de vida involucra tanto aspectos materiales como inmateriales en la violación de este derecho fundamental de la persona; comprende así no sólo una reparación indemnizatoria por la privación arbitraria de la vida, sino por la afectación y truncamiento al libre desarrollo de la personalidad, la interrupción de las 
A opinião do juiz resulta acertada toda vez que ressalta a existência de um dano ao projeto de vida sobre as consequências de ordem meramente material, como a perda de receitas. Neste sentido, a Corte não somente se equivoca por não reparar o dano ao projeto de vida de maneira autônoma, mas também contradiz sua doutrina anterior segundo a qual tais ramos indenizatórios não devem ser confundidos.

Outro caso de grande relevância é González y otras ("Campo Algodonero") Vs. México. Nesta ocasião, a Corte IDH declarou responsável o Estado pelo desaparecimento e posterior morte de três mulheres, dentre as quais se encontravam duas menores. Os fatos aconteceram dentro de um quadro de violência de gênero que deixou centenas de mulheres assassinadas na cidade de Juárez. No presente caso, a Corte não somente deixa de analisar o dano ao projeto de vida das vítimas, mas a mesma rechaça o pedido dos representantes de reparar tal dano. Nesta direção, a Corte Interamericana determinou que "os representantes não argumentaram suficientemente porque os atos do Estado afetaram o projeto de vida das vítimas”, agregando que “a reparação do dano ao projeto de vida não procede quando a vítima se encontra falecida, por ser impossível reabastecer as expectativas de realização que razoavelmente toda pessoa tem”28 (Corte IDH, 2009, Serie C No. 205, p. 148). É a primeira vez que a Corte

acciones que pudieron realizar ambos niños no sólo en lo laboral (pérdida de ingresos) sino también en aspectos espirituales, la realización personal y familiar, la consecución de planes y metas. Valorar el daño material estimándolo en pérdida de ingresos, resulta poco satisfactorio sobre todo tratándose de niños o adolescentes que no han adquirido aún propiamente una inserción laboral o realización profesional, ni una incorporación efectiva en el mercado de trabajo. El reconocimiento de un daño al proyecto de vida, resulta así más integral y consistente desde una perspectiva de protección a los derechos humanos, apartándose de corrientes esencialmente patrimonialistas”.

${ }^{28}$ Tradução livre, no original: “Además de que los representantes no argumentaron suficientemente por qué los actos del Estado afectaron el proyecto de vida de las jóvenes Herrera, González y Ramos, la Corte sostiene que la reparación por daño al proyecto de vida no procede cuando la víctima falleció, al ser imposible reponer las expectativas de realización que razonablemente toda persona tiene. Por tal razón, el Tribunal se abstiene de realizar mayores consideraciones al respecto". 
faz referência à necessidade de provar o dano ao projeto de vida em tais circunstâncias, em que fica clara a privação arbitrária da vida de mulheres e crianças. No presente caso anulou-se completamente qualquer possibilidade de desenvolvimento pessoal das vítimas, alterando também o projeto de vida dos familiares que dedicaram sua vida à procura da verdade. Além disso, cabe ressaltar que a Corte não precisou quais são os parâmetros necessários para creditar tal dano, tampouco que meios de prova seriam adequados para tal fim.

Por outro lado, surpreende ainda mais que, somente depois de dez anos, desde a sentença do caso Villagrán Morales, em que se analisou exaustivamente a noção do dano ao projeto de vida de crianças que já se encontravam falecidas, a Corte IDH tenha fundamentado a recusa da solicitação dos representantes justamente na morte das vítimas. Tal justificativa não deveria entrar em contradição com a constante jurisprudência da Corte de reparar as consequências do dano moral de vítimas falecidas? É uma razão suficiente privar a vítima de uma reparação integral argumentando a morte da mesma?

Maior relevância merece o paradigmático caso Gelman vs Uruguay (Corte IDH, 2011, Serie C No. 221). Os fatos aconteceram durante a ditadura civil-militar, em que as operações clandestinas incluíram muitos casos de subtração ou substituição da identidade e apropriação ilícita de crianças, para o qual mulheres grávidas foram retidas e mantidas vivas até dar à luz. Dentro deste marco, María Claudia García Casinelli, de 19 anos e grávida de sete meses, e seu marido Marcelo Ariel Gelman Schubaroff, foram presos em Buenos Aires e levados para um centro de detenção clandestino. Marcelo foi torturado desde o primeiro dia e seus restos mortais foram localizados apenas em 1989. María Claudia foi levada para Montevidéu por autoridades uruguaias, de forma clandestina, onde deu à luz a uma menina. Sua filha foi subtraída e entregada ilicitamente a um policial uruguaio e a sua mulher, que a registraram como filha própria com 
o nome de María Macarena Tauriño Vivian. Desde esse momento María Claudia se encontra desaparecida. O senhor Juan Gelman (avô da menina) e sua esposa, realizaram, por sua conta, averiguações sobre o ocorrido. No dia 31 de março de 2000 María Macarena teve, pela primeira, vez contato com seu avô, descobrindo o acontecido com seus pais biológicos. A partir desse momento, ela empreendeu as ações legais pertinentes para recuperar sua identidade verdadeira, adotando o nome de María Macarena Gelman García Iruuetagoyena.

$\mathrm{Na}$ audiência ante a Corte Interamericana, María Magdalena declarou como "a grave alteração nas suas condições de vida afetaram seu projeto de vida”, pois do momento em que conheceu sua verdadeira identidade ela empreendeu uma pesquisa de sua verdadeira origem e das circunstâncias do desaparecimento de sua mãe. Neste sentido, expressou a procura de sua mãe a foi consumindo, pois foi perdendo motivações, não conseguiu desfrutar [a vida] novamente, sempre pendente de alguma outra coisa que poderia ocorrer, sem projeção de vida para além de um mês, viajando entre Montevidéu e Buenos Aires (Corte IDH, 2011, Serie C No. 221, p. 36).

Concluiu que "sua vida não é muito mais que isso agora". A perita destacou justamente que: "ela foi afetada no mais íntimo de seu ser: sua identidade, pois o conhecimento dos fatos desestruturaram seu mundo interno”. A perita concluiu que María Macarena Gelman "apresenta sintomas que perturbam sua vida, lhe impedem retomar um projeto para seu futuro, e lhe causam dor" ${ }^{29}$

\footnotetext{
${ }^{29}$ Tradução livre. No original: "Según expresó, a partir de entonces "ha dedicado su vida a esto" y la búsqueda la "fue absorbiendo", pues "fu[e] perdiendo motivaciones, no h [a] podido volver a disfrutar, siempre pendiente y pensando que algo más puede pasar, [sin] proyección [de su vida] mas allá de un mes, viajando entre Montevideo y Buenos Aires". Concluyó que "no es mucho más que esto [su] vida ahora. Al respecto, la perita Deustch observó que "ella ha sido afectada en lo más intimo de su ser: su identidad", pues el conocimiento de los hechos "la hizo
} 
Na solicitação de medidas de reparação, tanto a Comissão IDH quanto os representantes fizeram alusão à alteração do projeto de vida das vítimas. A Comissão alegou que "o dano imaterial como consequência do desaparecimento de María Claudia García, resulta evidente”; como "as consequências da denegação de justiça aos familiares e o sofrimento psicológico intenso, a angústia, pena e alteração de seus projetos de vida” ${ }^{30}$ (Corte IDH, 2011, Serie C No. 221, p. 81). Os representantes alegaram que

O Estado violou a integridade pessoal de María Macarena em duas dimensões: pelo desaparecimento de sua mãe e pelas condições de seu nascimento e supressão de sua identidade, situação que mudou drasticamente o curso de sua vida modificando os projetos que tivera formulado em condições ordinárias de existência, pelo qual o Estado violou seu projeto de vida ${ }^{31}$ (Corte IDH, 2011, Serie C No. 221, p. 81).

Apesar das declarações da vítima e das solicitações dos representantes e da Comissão IDH, no momento de fixar a reparação a Corte não faz menção ao dano ao projeto de vida e simplesmente cita a "mudança nas condições de vida e restantes consequências de ordem imaterial ou não

tambalearse y le desestructuró su mundo interno”. La perita concluyó que María Macarena Gelman "presenta sintomas que perturban su vida, le impiden retomar un proyecto para su futuro, y le causan dolor".

${ }^{30}$ Tradução livre. No original: "La Comisión alegó que el daño inmaterial a raíz de la desaparición de María Claudia García resulta evidente, como también lo son las consecuencias lesivas de la denegación de justicia a sus familiares. Agregó que es presumible que sus familiares hayan tenido un sufrimiento psicológico intenso, angustia, pena y alteración de sus proyectos de vida en razón de las acciones estatales y la falta de justicia en un plazo razonable y la sanción respectiva de los involucrados en los hechos".

${ }^{31}$ Tradução livre, no original: "Uruguay violó su integridad personal en "dos dimensiones": por la desaparición de su madre y por las condiciones de su nacimiento y supresión de su identidad. Arguyeron que esto cambió "drásticamente el curso de [su] vida", "imponiéndole circunstancias vitales distintas que modificaron [los] planes y proyectos que hubiera formulado ante condiciones ordinarias de existencia”, por lo cual el Estado violó su proyecto de vida, lo cual persiste hasta la actualidad, ya que María Macarena Gelman dedica todos sus esfuerzos a la búsqueda de la verdad sobre el destino de su madre y los primeros días de su vida, así como a la búsqueda de justicia”. 
pecuniária sofridas por María Macarena Gelman”, incluindo a questão de maneira genérica dentro da categoria de dano imaterial e ordenando uma soma de dinheiro ${ }^{32}$ (Corte IDH, 2011, Serie C No. 221, p. 81).

Não se explica porque, dadas as circunstâncias do caso, em que se violam direitos fundamentais como a personalidade jurídica, a vida, integridade pessoal, liberdade pessoal, a família, o nome, a nacionalidade, e onde se suprime a identidade de uma pessoa que é o ponto de partida para a concretização do projeto de vida de um ser humano, a Corte tenha omitido dedicar-lhe um tratamento diferenciado. Mais confusa se torna sua decisão se for levado em consideração que, anos antes, no caso do Masacre de las Dos Erres, a mesma reconheceu, dentro de similares circunstâncias, que “a separação da vítima de seus familiares derivou no prejuízo não somente psicológico, mas também a seu projeto de vida, no âmbito familiar, razão pela qual, ante a falta de uma medida adequada para recobrar o reordenar seu projeto de vida, procedia uma indenização adicional por tais danos"33 (Corte IDH, 2011, Serie C No. 211, p. 81).

Novamente surge a pergunta: $\mathrm{O}$ que leva a Corte a mudar sua postura de uma sentença à outra? Por que a mesma não fundamenta tal mudança? A justificativa de falecimento da vítima dadas as circunstâncias do caso, não pode ser invocada. A Corte também não menciona ausência de prova do dano. Então, por que a Corte IDH novamente omite falar a respeito aos pedidos de reparação dos representantes da vítima?

\footnotetext{
${ }^{32}$ Tradução livre, no original: “...es particularmente relevante el cambio en las condiciones de vida y las restantes consecuencias de orden inmaterial o no pecuniario que sufridas por María Macarena Gelman. En consecuencia, la Corte estima pertinente fijar una cantidad, en equidad, como compensación por concepto de daños inmateriales..."

${ }^{33}$ Tradução livre. No original: "Al respecto, en el caso del sobreviviente Ramiro Osorio Cristales el sufrimiento por la sustracción y retención ilegal por el Kaibil Santos López y separación de sus familiares (supra párrs. 179 y 180) derivó en afectaciones no sólo psicológicas sino también a su proyecto de vida dentro de un entorno familiar, inclusive en su destierro. En función de la falta de elementos para ordenar una medida adecuada para recobrar o reorientar su proyecto de vida, procede una indemnización adicional por dichos daños ".
} 
Outro caso de similares características é Contreras y otros Vs. El Salvador, referente a desaparecimentos forçados de crianças por parte de membros do exército militar, seguido da subtração da identidade e separação das vítimas de seus familiares. Dentre as vítimas somente se encontrou o paradeiro de uma delas, que foi objeto de abusos físicos, sexuais e psicológicos enquanto esteve sob a guarda do soldado que se apropriou da mesma. A Corte estabeleceu que "a subtração ilegal da vítima de seus pais biológicos, ameaça a vida, supervivência e desenvolvimento das crianças, englobando aqueles aspectos relacionados com o físico, mental, espiritual, moral, psicológico e social”34 (Corte IDH, 2011, Serie C No. 232, p. 34) , contudo, a Corte Interamericana não menciona o dano ao projeto de vida, nem faz referência ao detrimento do mesmo como consequência das alegadas violações, mesmo tendo em conta, no momento de declarar a responsabilidade do Estado pela violação do direito a identidade, o estabelecido pela perita, a qual declarou que o "desconhecimento da vítima de suas próprias raízes a impede ter um projeto de vida no qual se colocar”35 (Corte IDH, 2011, Serie C No. 232, p. 44).

\footnotetext{
${ }^{34}$ Tradução livre, no original: “...Esta situación se ve acentuada cuando se está frente a un patrón sistemático de violaciones de derechos humanos y cuando se trata de niños o niñas, como en el presente caso, dado que la sustracción ilegal de sus padres biológicos también pone en riesgo la vida, supervivencia y desarrollo de los niños y niñas, este último entendido de una manera amplia abarcando aquellos aspectos relacionados con lo físico, mental, espiritual, moral, psicológico y social...”

${ }^{35}$ Tradução livre, no original: “En esta línea, resulta ilustrativo lo señalado por la perita Yáñez en cuanto a que '[s] de daña el centro mismo de la identidad de Gregoria porque se le roba el nombre, pero también se le roba su familia, también se le roba su lugar, su comunidad, su pueblo. Ella desconoce sus propias raíces y esto le da como un vacío no saber quién es pero también le impide tener un proyecto de vida en el cual ella colocarse. Ella se ha pasado la vida diciendo, quién soy, qué edad tengo, ella dice que a veces como le hacían hacer trabajos de adulto ella decía a lo mejor soy más vieja de lo que soy, ella no se ubicaba en qué edad tenía ni tampoco a quién se parecía, a quién me parezco, quién soy, cómo es mi apellido, cómo es mi nombre, en definitiva quién soy yo."
} 
Um relevante caso, e que constituiu uma grande oportunidade para que a Corte se pronunciasse sobre a existência de um dano ao projeto de vida tanto individual quanto familiar, é o caso Atala Riffo y niñas Vs. Chile. Neste caso, a Corte IDH declarou a responsabilidade do Estado, entre outras violações, pelo tratamento discriminatório e a interferência arbitrária na vida privada e familiar sofridos pela vítima. Tal tratamento se viu refletido no processo judicial, como consequência de sua orientação sexual, o que resultou na retirada da guarda de suas filhas. Nesta ocasião, entre outras questões, a Corte ressaltou que “o direito à não discriminação por orientação sexual inclui sua expressão e consequências necessárias no projeto de vida das pessoas"36 (Corte IDH, 2012, Serie C No. 239, p. 46-47) e assim mesmo, "encontra-se ligado ao conceito de liberdade e à possibilidade de todo ser humano de se autodeterminar e escolher livremente as opções e circunstâncias que dão sentido a sua existência conforme as suas próprias opções e convicções”37 (Corte IDH, 2012, Serie C No. 239, p. 48). Em outras palavras, podemos afirmar que a Corte não está se referindo a outra coisa que o direito de toda pessoa a escolher livremente um projeto de vida que está intimamente ligado à orientação sexual da pessoa e ao direito de gozar da mesma. Apesar da Corte Interamericana ter declarado responsável o Estado, pela violação dos direitos à não discriminação e à vida privada e familiar que derivou na separação da vítima de suas filhas, esta não analisa a existência de um dano ao projeto de vida, e no momento

\footnotetext{
${ }^{36}$ Tradução livre, no original: "La Corte Interamericana considera necesario recalcar que el alcance del derecho a la no discriminación por orientación sexual no se limita a la condición de ser homosexual, en sí misma, sino que incluye su expresión y las consecuencias necesarias en el proyecto de vida de las personas."

${ }^{37}$ Tradução livre, no original: “En este sentido, la orientación sexual de una persona también se encuentra ligada al concepto de libertad y la posibilidad de todo ser humano de autodeterminarse y escoger libremente las opciones y circunstancias que le dan sentido a su existencia, conforme a sus propias opciones y convicciones.”
} 
de ditar as medidas de reparação somente ordena que seja disponibilizada uma soma de dinheiro por danos imateriais (Corte IDH, 2012, Serie C No. 239, p. 86).

Dentro deste grupo de sentenças analisadas é ainda possível encontrar numerosos casos que, por questões de espaço, não foram analisados. Por esta razão, somente nos limitamos a introduzir aqueles casos que, por seu conteúdo refletem com maior claridade a falta de unificação da jurisprudência da Corte IDH.

\section{CONSIDERAÇÕES FINAIS}

Após serem analisadas numerosas sentenças proferidas pela Corte Interamericana de Direitos Humanos ao longo de quinze anos de jurisprudência, pode-se observar que a noção de projeto de vida e, portanto, o impacto que seu detrimento acarreta na vida de todo ser humano, teve sua gênesis recentemente no plano internacional, em particular dentro do Sistema Interamericano de Direitos Humanos. A vontade da Corte IDH de analisar mais profundamente a matéria refletiu-se claramente em algumas sentenças, em que a mesma reconheceu amplamente a relevância que $o$ direito ao projeto de vida envolve e, consequentemente, a necessidade de reparar seu dano.

Resulta evidente, contudo, que a Corte Interamericana ainda não estabeleceu princípios lógicos e claros que permitam avaliar com precisão este tipo de dano. Neste sentido, não foi estabelecido por esta se é um dano que precisa ser provado e, neste caso, de que maneira procederia a prova daquele. Assim mesmo, não pode ser deduzido da jurisprudência da Corte, se o dano ao projeto de vida é um dano quantificável, e no caso de o ser, como se quantificaria. Não foi delimitado com claridade o umbral que oscila entre o dano ao projeto de vida e o dano moral, assim como 
quais são as caraterísticas que permitem diferenciar ambos. Esta falta de diferenciação levou a Corte IDH, em muitas ocasiões, e como foi analisado anteriormente, a unificar ambos conceitos em um solo ramo indenizatório.

Outra dificuldade que aparentemente enfrenta a Corte é relativa à determinação da categoria reparatória. Encontra-se casos em que esta inclui o dano ao projeto de vida dentro dos danos imateriais, bem como casos em que é considerado como um dano material, sem deixar de recordar que em determinadas sentenças a Corte IDH o repara como medida de satisfação e não repetição.

Como consequência desta falta de claridade na análise do dano ao projeto de vida, a jurisprudência deste órgão não foi suficientemente constante e uniforme para abrir, de maneira concreta, uma nova via de reparações no que se refere aos prejuízos e frustrações do projeto de vida das vítimas. Por outro lado, as razões dessa falta de uniformidade nas decisões da Corte e a mudança de posturas que esta adota entre sentenças de características similares, ainda não foram explicadas. Isto gera maiores incertezas na matéria e dificulta sua progressão dentro do Sistema Interamericano de Direitos Humanos.

Não pode se negar, entretanto, as dificuldades que acarretam avaliar o dano ao projeto de vida dada as distintas dimensões que o mesmo envolve dentro de cada caso concreto. Mais ainda quando se considera tal como explicou o juiz Carlos Vicente De Roux Rengifo, que "não toda modificação nas condições de existência merece ser indenizada. Deve se tratar de mudanças de grandes dimensões, que afetem profundamente o marco afetivo e espiritual onde se desenvolve a família, ou bloqueiem uma evolução profissional que consumiu grandes esforços e dedicação”38 (Voto

\footnotetext{
${ }^{38}$ Tradução livre. No original: "No toda modificación de las condiciones de existencia merece ser indemnizada. Debe tratarse de cambios de mucha entidad, que trastoquen a fondo, por ejemplo, el marco afectivo y espiritual en que se desenvuelve la vida de la familia, o trunquen una evolución profesional que ha consumido grandes esfuerzos y empeños".
} 
Juíz Vicente de Roux, Corte IDH, 1998, Serie C No. 42), entre outros possíveis prejuízos de enorme magnitude. A difícil avaliação deste dano, contudo, não pode levar à omissão de seu tratamento, nem impedir que sejam ditadas medidas que garantam, dentro das possibilidades e de maneira progressiva, o máximo nível de reparação a favor das vítimas.

Talvez seja um bom momento para que a Corte IDH comece a delinear com maior precisão as bases sobre as quais se deverá construir esta nova noção de dano e sua correspondente reparação, ou, ao contrário, justifique com argumentos claros o abandono desta categoria.

\section{REFERÊNCIAS}

ALVES DA FROTA, Hidemberg; LEITE BIÃO, Fernanda. A dimensão existencial da pessoa humana, o dano existencial e o dano ao projeto de vida: reflexões à luz do direito comparado. Cadernos da Escola de Direito e Relações Internacionais, Curitiba, v. 1, 13:129-163, Disponível em: <http://apps.unibrasil.com.br/revista/index.php/direito/article/viewFile/419/360>.

ALVES DE ALMEIDA, Amaro. Dano existencial. A tutela da dignidade da pessoa humana. In: Revista de "Direito Privado", n. 24, oct./dic. 2005.

BILOTTA, Franceso. Attraverso il danno esistenziale, oltre il danno esistenziale. In: "Responsabilitá civile e previdenza". Milano: Giuffré, 2006. p. 1.0511.055 .

BURGOS, Osvaldo R. El daño extrapatrimonial de los llamados damnificados indirectos ante supuestos de irreversibilidad de las consecuencias dañosas. Daño al proyecto de vida, daño existencial, daño moral o el hombre como límite del derecho. In: CONGRESO INTERNACIONAL DE DERECHO DE DAÑOS, 8. 2005, Buenos Aires. Buenos Aires: Biblioteca Electrónica de la Asociación de Abogados de Buenos Aires, 9 al 10 de junio del 2005.

CALDERÓN GAMBOA, Jorge Francisco. El daño al proyecto de vida por violación de los derechos humanos. México: Porrúa, 2005. 
CORTE I.D.H. Loayza Tamayo Vs. Perú. Sentencia de 17 de septiembre de 1997. Serie C No. 33.

. Cantoral Benavides Vs. Perú. Sentencia de 18 de agosto de 2000. Serie C No. 69.

. Loayza Tamayo Vs. Perú. Sentencia de 27 de noviembre de 1998. Serie C No.42.

. Castillo Páez Vs. Perú. Sentencia de 27 de noviembre de 1998. Serie C No. 43.

. Baena Ricardo y otros Vs. Panamá. Sentencia de 2 de febrero de 2001. Serie C No. 72.

. Barrios Altos Vs. Perú. Sentencia de 14 de marzo de 2001. Serie C No.75.

. Cantoral Benavides Vs. Perú. Sentencia de 3 de diciembre de 2001. Serie C No. 88.

. Bulacio Vs. Argentina. Sentencia de 18 de septiembre de 2003. Serie C No. 100.

. Masacre Plan de Sánchez Vs. Guatemala. Sentencia de 29 de abril de 2004. Serie C No. 105.

. Molina Theissen Vs. Guatemala. Sentencia de 4 de mayo de 2004. Serie C No. 106. C No. 108.

. Molina Theissen Vs. Guatemala. Sentencia de 3 e julio de 2004. Serie . Hermanos Gómez Paquiyauri Vs. Perú. Sentencia de 8 de julio de 2004. Serie C No. 110.

. Tibi Vs. Ecuador. Sentencia de 7 de septiembre de 2004. Serie C No. 114.

. Masacre Plan de Sánchez Vs. Guatemala. Sentencia de 19 de noviembre de 2004. Serie C No. 116.

. Caso de las niñas Yean y Bosico Vs. República Dominicana. Sentencia de 8 de septiembre de 2005. Serie C No. 130. 
. Gutiérrez Soler Vs. Colombia. Sentencia de 12 de septiembre de 2005. Serie C No. 132.

. Goméz Palomino Vs. Perú. Sentencia de 22 de noviembre de 2005. Serie C No.136.

. Villagrán Morales y otros ("niños de la calle") Vs. Guatemala Sentencia de 19 de noviembre 1999. Serie C No. 63.

. Villagrán Morales y otros (“ niños de la calle”) Vs. Guatemala. Sentencia de 26 de mayo de 2001. Serie C No. 77.

. Tibi Vs. Ecuador. Sentencia de 7 de septiembre de 2004. Serie C No. 114.

. Gutiérrez Soler Vs. Colombia. Sentenia de 12 de septiembre de 2005. Serie C No. 132.

. Garibaldi Vs. Brasil. Sentencia de 23 de Septiembre de 2009. Serie C No. 203.

. Dacosta Cadogan Vs. Barbados. Sentencia de 24 de septiembre de 2009. Serie C No. 204.

. González y otras ("Campo Algodonero") Vs México. Sentencia de 16 de noviembre de 2009. Serie C No. 205.

. Barreto Leiva Vs. Venezuela. Sentencia de 17 de noviembre de 2009. Serie C No. 206.

. Usón Ramírez Vs. Venezuela. Sentencia de 20 de noviembre de 2009. Serie C No. 207.

. Radilla Pacheco Vs. México. Sentencia de 23 de noviembre de 2009. Serie C No. 209.

. Masacre de las Dos Erres Vs. Guatemala. Sentencia de 24 de noviembre de 2009. Serie C No. 211.

. Chitay Nech y otros Vs. Guatemala. Sentencia de 25 de mayo de 2010. Serie C No. 212.

. Manuel Cepeda Vargas Vs. Colombia. Sentencia de 25 de Mayo de 2010. Serie C No. 213. 
. Comunidad Indigena Xakmok Kasek Vs. Paraguay. Sentencia de 24 de agosto de 2010. Serie C No. 214.

. Fernández Ortega y otros Vs. México. E Sentencia 30 de agosto de 2010. Serie C No. 215.

. Rosendo Cantu yotras Vs. México. Sentencia de 31 de agosto de 2010. Serie C No. 216.

. Ibsen Cárdenas e Ibsen Peña Vs. Bolivia. Sentencia de 1 de septiembre de 2010. Serie C No. 217.

. Vélez Loor Vs. Panama. Sentencia de 23 de noviembre de 2010. Serie C No.218.

. Gomes Lund y otros (Guerrilla do Araguaia) Vs. Brasil. Sentencia de 24 de noviembre de 2010. Serie C No. 219.

. Cabrera Garcia y Montiel Flores Vs. México. Sentencia de 26 de noviembre de 2010. Serie C No. 220.

. Gelman Vs. Uruguay. Fondo y Reparaciones. Sentencia 24 de febrero 2011. Serie C No. 221.

. Salvador Chiriboga Vs. Ecuador. Sentencia de 3 de marzo de 2011. Serie C No. 222.

. Abrill Alosilla Vs. Perú. Sentencia 4 de marzo de 2011. Serie C No. 223.

. Vera Vera y otra Vs. Ecuador. Sentencia de 19 de mayo de 2011. Serie C No. 226 .

. Caso Chocron Chocron Vs. Venezuela. Sentencia 1 de julio de 2011. Serie C No. 227.

. Mejia Idrovo Vs. Ecuador. Sentencia de 5 de julio de 2011. Serie C No. 228.

. Torres Millatura y otros Vs. Argentina. Sentencia de 26 de agosto de 2011. Serie C No. 229

. Grande Vs. Argentina. Sentencia de 31 de agosto de 2011. Serie C No. 231. 
. Contreras y otros Vs. Ecuador. Sentencia de 31 de agosto de 2011. Serie C No. 232.

. Lopez Mendoza Vs. Venezuela. Sentencia de 1 de septiembre de 2001. Serie C No. 233.

. Barbani Duarte y otros Vs Uruguay. Sentencia de 13 octubre de 2011. Serie C No. 234.

. Fleury y otros Vs. Haiti. Sentencia de 23 de noviembre de 2011. Serie C No. 236.

. Família Barrios Vs. Venezuela. Sentencia de 24 de noviembre de 2011. Serie C No. 237.

. Fontevecchia y D’Amico Vs. Argentina. Sentencia de 29 de noviembre de 2011. Serie C No. 238.

. Atala Riffo y niñas Vs. Chile. Sentencia de 24 de febrero de 2012. Serie C No. 239.

. González Medina y familiares Vs. Republica Dominicana. Sentencia de 27 de febrero de 2012. Serie C No. 240.

. Pacheco Teruel y otros Vs. Honduras. Sentencia 27 de abril 2012. Serie C No. 241.

. Fomeron e hija Vs. Argentina. Sentencia de 27 de abril de 2012. Serie C No. 242.

. Díaz Peña Vs. Venezuela. Sentencia de 26 de junio de 2012. Serie C No. 244.

. Pueblo Indígena Kichwa de Sarayacu Vs. Ecuador. Sentencia de 27 de junio de 2012. Serie C No. 245.

. Furlan y familiares Vs. Argentina. Sentencia de 31 de agosto de 2012. Serie C No. 246.

. Palma Mendoza y otros Vs. Ecuador. Sentencia de 3 de septiembre de 2012. Serie C No. 247.

. Vélez Restrepo y familiares Vs. Colombia. Sentencia de 3 de septiembre de 2012. Serie C No. 248. 
. Uzcategui y otros Vs. Venezuela. Sentencia de 3 de septiembre de 2012. Serie C No. 249.

. Masacres de Rio Negro Vs. Guatemala. Sentencia de 4 de septiembre de 2012. Serie C No. 250.

. Nadege Dorzema y otros Vs. República Dominicana. Sentencia de 24 octubre de 2012. Serie C No. 251.

. Masacres de El Mozote y lugares aledaños Vs. El Salvador. Sentencia de 25 de octubre de 2012. Serie C No. 252.

. Gudiel Alvarez y otros (diário militar) Vs. Guatemala. Sentencia de 20 de noviembre de 2012. Serie C No. 253.

. Mohamed Vs. Argentina. Sentencia de 23 de noviembre de 2012. Serie C No. 255.

. Castillo González y otros Vs. Venezuela. Sentencia de 27 de noviembre de 2012. Serie C No. 256.

. Artavia Murillo y otros. (fertilización in vitro) Vs. Costa Rica. Sentencia de 28 de noviembre de 2012. Serie C No. 257.

. Garcia y familiares Vs. Guatemala. Sentencia de 29 de noviembre. Serie C No. 258.

. Masacre de Santo Domingo Vs. Colombia. Sentencia de 30 de noviembre de 2012. Serie C No. 259.

. Mendoza y otros Vs. Argentina. Sentencia de 14 de mayo de 2013. Serie C No. 260.

. Suarez Peralta Vs. Ecuador. Sentencia de 21 de mayo de 2013. Serie C No. 261.

. Memoli Vs. Argentina. Sentencia de 22 de agosto de 2013. Serie C No. 265.

. Caso de la Corte Suprema de Justicia ( Quintana Coello y otros) Vs. Ecuador. Sentencia de 23 de agosto de 2013. Serie C No. 266.

. García Lucero y otros Vs. Chile. Sentencia de 28 de agosto de 2013. Serie C No. 267. 
. Caso del Tribunal Constitucional ( Camba Campos y otros) Vs. Ecuador. Sentencia de 28 de agosto de 2013. Serie C No. 268.

. Luna López Vs. Honduras. Sentencia de 10 de octubre de 2013. Serie C No. 269.

. Comunidades Afrodescendientes Desplazadas de la Cuenca del Río Cacarica (operacion Genesis) Vs. Colombia. Sentencia de 20 de noviembre de 2013. Serie C No. 270.

. Gutiérrez y família Vs. Argentina. Sentencia de 25 de noviembre 2013. Serie C No. 271.

. Familia Pacheco Tineo Vs. Bolivia. Sentencia de 25 de noviembre de 2013. Serie C No. 272.

. García Cruz y Sánchez Silvestre Vs. México. Sentencia de 26 de noviembre. Serie C No. 273.

. Osorio Rivera y Familiares Vs. Perú. Sentencia de 26 de noviembre de 2013. Serie C No. 274.

J. Vs. Perú. Sentencia de 27 de noviembre de 2013. Serie C No. 275.

DÍAZ CÁCEDA, Joel. El daño a la persona y el daño al proyecto de vida. Una aproximación a la doctrina y su aplicación en el ámbito nacional e internacional. Lima: Jurista Editores, 2006.

DÍAZ SCHWERTER, José. La resarcibilidad del daño no patrimonial en América Latina. Disponível em: <htpp://www.juridicas.unam.mx.sisjur/civil/ pdf/1-63s.pdfs.

FAPPIANO, Oscar L. El daño al proyecto de vida en proyecto de Código Civil de la República Argentina. In: Revista “Abogados”, Lima, año IV, n. 7, p. 16, 2002.

FAÚNDEZ LEDESMA, Héctor. El sistema Interamericano de Protección de los Derechos Humanos. Aspectos Institucionales y Procesales. San José de Costa Rica: Instituto Interamericano de Derechos Humanos, 1999.

FERNÁNDEZ SESSAREGO, Carlos. ¿Existe un daño al proyecto de vida? In: VÁRIOS AUTORES. “Scritti in onore di Guido Gerin”. Padova: Cedan, 1996. 
. El daño a la persona en el Código civil de 1984. In: VÁRIOS AUTORES. Libro Homenaje a José León Barandiarán. Lima: Editorial Cultural Cuzco, 1985. p. 161-222.

. El Daño al Proyecto de Vida em uma reciente sentencia de la Corte Interamericana de Derechos Humano. In: Revista de Responsabilidad Civil y Seguros, Buenos Aires, p. 659-700, jul./ago. 2000.

GALDÓS, Jorge Mario ¿Hay un daño al proyecto de vida? Buenos Aires: “La Ley”, 2005-F-1005.

GARCÍA RAMÍREZ, Sergio. Dos temas de la Jurisprudencia Interamericana: "Proyecto de Vida” y “Amnistía”. Revista de Derecho y Jurisprudencia y en Gaceta de los Tribunales, Santiago de Chile, tomo XCV, n. 3, p. 61-75, mayo/ ago. 1998.

. Las reparaciones en la jurisprudencia de la Corte Interamericana de

Derechos Humanos. In: “Anuario Iberoamericano de Justicia Constitucional”, Madrid: Centro de Estudios Políticos y Constitucionales, n. 3, p. 323, 342, 1999. MOSSET ITURRASPE, Jorge. "El daño fundado en la dimensión del hombre en su concreta realidad”. In: Revista de Derecho Privado y Comunitario, "Daños a la persona”, Santa Fe: Ed. Rubinzal-Culzoni, n. 1, p. 9, 1992a.

. El valor de la vida humana. 4. ed. Buenos Aires: Rubinzal-Culzoni, 2002. p. 30-31.

. El Valor de la Vida Humana. Tercera edición. Sant Fe: Rubinzal-Culzoni, 1992b. 379p.

PINTO OLIVEROS, Sheraldine. Il danno alla persona nell'esperienza peruviana. In: COMANDÉ, Giovanni; DOMENICI, Ranieri. La valutazione delle macropermanenti. Edizioni ETS, 2005. p. 125-127.

SALADO OSUNA, Ana. Los casos peruanos ante la Corte Interamericana de Derechos Humanos. Trujillo: Editorial Normas Legales, 2004. p. 431.

SARTRE, Jean Paul. El Ser y la Nada. Buenos Aires: Editorial Iberoamericana, 1948. $775 \mathrm{p}$. 
SCHÄFER, Gilberto; MARTINS MACHADO, Carlos Eduardo. A reparação do dano ao projeto de vida na Corte Interamericana de Direitos Humanos. Revista de Direitos Fundamentais e Democracia, Curitiba, v. 13, n. 13, p. 179197, jan./jun. 2013.

SELVADORAY, Jonathan. Pérdida de oportunidad y derechos humanos. Liber Amicorum, Héctor Fix-Zamudio; Corte Interamericana de Derechos Humanos, presentado por César Gaviria. Volumen II. San José, Costa Rica: Corte Interamericana de Derechos Humanos; Unión Europea, 1998.

TAMAYO JARAMILLO, Javier. De la Responsabilidad Civil. Editorial Temis, 1999. 415p. Tomo I.

VARSI ROSPIGLIOSI, Enrique. Los derechos de la persona, el proyecto de vida y el deporte en el pensamiento del maestro peruano Carlos Fernández Sessarego. Diario “El Peruano”, Lima, 2007.

ZAVALA DE GONZÁLEZ, Matilde. Daños a proyectos de vida. Revista de Responsabilidad Civil y Seguros, Buenos Aires, año VII, n. 4, abr. 2005

Recebido em: 18/10/2014

Revisões requeridas em: 23/3/2015

Aceito em: 27/3/2015 